Article

\title{
Anabolic Properties of Mixed Wheat-Legume Pasta Products in Old Rats: Impact on Whole-Body Protein Retention and Skeletal Muscle Protein Synthesis
}

\author{
Insaf Berrazaga ${ }^{1,2, \dagger}{ }^{\dagger}$ Jérôme Salles ${ }^{1, \dagger}$, Karima Laleg ${ }^{1,2}$, Christelle Guillet ${ }^{1}$, Véronique Patrac ${ }^{1}$, \\ Christophe Giraudet ${ }^{1}$, Olivier Le Bacquer ${ }^{1}$, Marine Gueugneau ${ }^{1}$, Philippe Denis ${ }^{1}$, Corinne Pouyet ${ }^{1}$, \\ Angelique Pion ${ }^{1}$, Phelipe Sanchez ${ }^{1}$, Yves Boirie ${ }^{1,3}$ (D) , Valérie Micard ${ }^{2, *} * \mathbb{D}$ and Stéphane Walrand ${ }^{1,3, *}$ \\ 1 UNH, Unité de Nutrition Humaine, CRNH, Université Clermont Auvergne, INRA, Auvergne, \\ 63000 Clermont-Ferrand, France; berrazaga.insaf@gmail.com (I.B.); jerome.salles@inrae.fr (J.S.); \\ karimalaleg@gmail.com (K.L.); christelle.guillet@uca.fr (C.G.); veronique.patrac@inrae.fr (V.P.); \\ christophe.giraudet@inrae.fr (C.G.); olivier.le-bacquer@inrae.fr (O.L.B.); marine.gueugneau@inrae.fr (M.G.); \\ philippe.denis@inrae.fr (P.D.); corinne.pouyet@inrae.fr (C.P.); angelique.pion@inrae.fr (A.P.); \\ phelipe.sanchez@inrae.fr (P.S.); yves.boirie@inrae.fr (Y.B.) \\ 2 IATE Agropolymer Engineering and Emerging Technologies, University Montpellier, INRA, CIRAD, \\ Montpellier SupAgro, 34060 Montpellier, France \\ 3 Service de Nutrition Clinique, Centre Hospitalier Universitaire (CHU) Gabriel Montpied, \\ 63000 Clermont-Ferrand, France \\ * Correspondence: valerie.micard@supagro.fr (V.M.); stephane.walrand@inrae.fr (S.W.); \\ Tel.: +33-49-961-2889 (V.M.); +33-47-317-8281 (S.W.) \\ + These authors contributed equally to this study.
}

Received: 27 March 2020; Accepted: 26 May 2020; Published: 29 May 2020

\begin{abstract}
The mechanisms that are responsible for sarcopenia are numerous, but the altered muscle protein anabolic response to food intake that appears with advancing age plays an important role. Dietary protein quality needs to be optimized to counter this phenomenon. Blending different plant proteins is expected to compensate for the lower anabolic capacity of plant-based when compared to animal-based protein sources. The objective of this work was to evaluate the nutritional value of pasta products that were made from a mix of wheat semolina and faba bean, lentil, or split pea flour, and to assess their effect on protein metabolism as compared to dietary milk proteins in old rats. Forty-three old rats have consumed for six weeks isoproteic and isocaloric diets containing wheat pasta enriched with $62 \%$ to $79 \%$ legume protein (depending on the type) or milk proteins, i.e., casein or soluble milk proteins (SMP). The protein digestibility of casein and SMP was 5\% to $14 \%$ higher than legume-enriched pasta. The net protein utilization and skeletal muscle protein synthesis rate were equivalent either in rats fed legume-enriched pasta diets or those fed casein diet, but lower than in rats fed SMP diet. After legume-enriched pasta intake, muscle mass, and protein accretion were in the same range as in the casein and SMP groups. Mixed wheat-legume pasta could be a nutritional strategy for enhancing the protein content and improving the protein quality, i.e., amino acid profile, of this staple food that is more adequate for maintaining muscle mass, especially for older individuals.
\end{abstract}

Keywords: sarcopenia; skeletal muscle; legume-enriched pasta; faba bean; lentil; split pea; protein quality; muscle protein synthesis rate

\section{Introduction}

Sarcopenia is a syndrome that is characterized by a progressive and generalized loss of skeletal muscle mass and function with a risk of adverse effects, such as physical disability, metabolic 
abnormalities, poor quality of life, and increased risk of death [1]. The mechanisms that are responsible for sarcopenia are numerous and still only partly understood, but the decreased muscle anabolic response to meal-associated amino acids and insulin that appears during aging plays a key role [2-5]. In order to overcome this 'anabolic resistance' phenomenon [6] and mitigate age-related muscle loss, it is recommended to increase protein intake for older people to $1-1.2 \mathrm{~g} / \mathrm{kg}$ bodyweight/d [7,8] and optimize the quality of dietary protein intake to meet the needs of older people [9].

There is mounting evidence that proteins that are derived from animal sources, i.e., meat, egg, milk and its constitutive proteins (casein and whey proteins), are strong enhancers of skeletal muscle protein synthesis rate (for reviews, see [10-12]). Nevertheless, older people generally intake less animal products, due to reduced chewing efficiency, cognitive dysfunction, blunted appetite for rich protein foods, and/or socio-economic factors. Moreover, excessive consumption of animal-based foods might increase the risk for cardiovascular diseases, chiefly due to high intake of saturated fat [13-15]. Therefore, it is necessary to find new protein sources that are adapted for older people. Plant-source proteins could be a valuable strategy for older people to prevent the health risks that are associated with consuming animal products and promote better protein consumption, as plant-based protein sources are rich in fiber and micronutrients and have antioxidant properties [16,17].

Several studies have evaluated the effect of plant-based protein sources, i.e., raw faba beans [18-21], raw peas, cooked lentils or cooked beans [22-26], soy proteins [27-35], faba bean proteins [36], and wheat proteins [33] when compared with animal-based protein sources on body protein retention and metabolism in young or old rats, pigs, or humans. All have reported a positive effect of animal proteins on protein metabolism in young animals or humans as compared to plant-based protein sources, regardless of their form, e.g., raw or cooked, protein isolate, or protein hydrolysate. Yang et al. [37] showed that muscle protein synthesis rate was $40 \%$ lower in elderly subjects after soy protein intake than after ingesting the same amount of whey protein. Gorissen et al. [38] also showed that the muscle protein synthesis rate was 30\% lower in older men after ingesting $35 \mathrm{~g}$ of wheat protein than after ingesting an equal amount of casein. Overall, regardless of age, most of these studies found that plant-based protein sources have less potential to enhance protein metabolism and retention rate at the whole-body or muscle level in animals and humans when compared to animal-based proteins. This difference could be explained by the fact that plant proteins are less digestible [39] and relatively less rich in essential and biologically-active amino acids, like leucine than animal proteins [11]. Plant-based proteins are also known to be deficient in certain essential amino acids (EAA), like lysine, methionine, threonine, and/or tryptophan [40], which could limit in vivo protein synthesis.

Blending different plant-based proteins could theoretically compensate for the lower anabolic potential of these single protein sources [11]. Combining various plant-based protein sources, such as cereals (deficient in lysine and threonine) and legumes (deficient in sulfur amino acids), could provide a more balanced amino acid profile to meet body needs, especially in EAA [41]. In a study on young rats, Márquez-Mota et al. [42] evaluated the effect of cereal and legume protein blends, i.e., corn protein isolate-soy protein isolate and corn protein isolate-black bean protein concentrate, on the anabolic signaling pathway that is involved in protein synthesis. Overall, they demonstrated that plant protein blends had greater effect than a single plant protein source. Torres et al. [43-45], Laleg et al. [46], and Giménez et al. [47] also demonstrated the beneficial effects of incorporating 10\%-35\% legume flour in wheat pasta and 30\% legume flour in corn pasta on protein digestibility and net protein utilization (NPU) in young rats. However, to our knowledge, the nutritional benefits of such combinations in older individuals has never yet been studied.

The aim of this study was to evaluate the efficiency of plant-based protein sources, i.e., wheat pasta enriched with different legume flours (faba bean, lentil, or split pea), on protein digestibility and metabolism, i.e., protein retention, muscle protein synthesis rate, and muscle protein accretion as compared to animal-based dietary proteins, in old rats. For this purpose, we prepared wheat pasta enriched with faba bean, lentil, or split pea flour, as per the classical steps of industrial pasta production (hydration, mixing, extrusion, drying) [48], and then cooked and dried the pasta at low temperature 
to produce a material that was fed to the rats. We evaluated the protein quality indexes of each legume-enriched pasta, and compared body composition, liver, and skeletal muscle protein contents and skeletal muscle protein synthesis rate in old rats fed legume-enriched pasta or high-nutritional-value animal proteins, i.e., slow digestive protein (casein) and fast digestive protein (soluble milk proteins).

\section{Materials and Methods}

\subsection{Raw Material for Pasta Manufacturing}

The faba bean (Vicia faba), lentil (Lens culinaris) and split pea (Pisum Sativum L.) flours were supplied by GEMEF Industries (Aix-en-Provence, France), Celnat (Saint-Germain-Laprade, France), and Moulin des Moines (Krautwiller, France), respectively. Panzani provided wheat (Triticum durum) semolina (Marseille, France).

\subsection{Pasta Manufacturing}

All pasta were produced at the IATE joint research unit (SupAgro-INRA-Univ Montpellier-CIRAD, Montpellier, France) following the standard pasta-making process steps, i.e., hydration, mixing, and extrusion $\left(40^{\circ} \mathrm{C}\right)$ in a pilot press (Bassano, Lyon, France) and drying at low temperature $\left(55^{\circ} \mathrm{C}\right.$, $15 \mathrm{~h}$ ) in a pilot drier (AFREM, Lyon, France) [48].

Each pasta was cooked for its optimal cooking time (OCT) $+1 \mathrm{~min}$. to ensure complete starch gelatinization, then dried at low temperature $\left(40^{\circ} \mathrm{C}, 24 \mathrm{~h}\right)$, and ground down to produce a food material ready for the rats to consume.

Three isoproteic $(21 \% \mathrm{db})$ legume-enriched pasta were manufactured:

1. A $38 \%$ wheat semolina- $62 \%$ faba bean flour pasta (F-pasta)

2. A $35 \%$ wheat semolina-65\% lentil flour pasta (L-pasta)

3. A $21 \%$ wheat semolina-79\% split pea flour pasta (P-pasta)

\subsection{Diet Manufacturing}

Diets were manufactured by the UPAE (Unité de Préparation des Aliments Expérimentaux, INRA, Jouy-en-Josas, France). The diets incorporated the legume-enriched pasta produced by the IATE or casein and soluble milk proteins provided by Lactalis (Torcé, France). Soluble milk proteins, noted as SMP, indicate whey proteins in this present work. Diet compositions (Table 1) were calculated to ensure that both diets that were made with legume-enriched pasta and control diets (casein and SMP) were isoproteic (same protein content) and isocaloric. Dietary amino acid levels (Table 2) were analyzed by the Agrobio laboratory (Rennes, France) according to the method that was published in Commission Regulation (EC) No 152/2009.

Table 1. Chemical composition of legume-enriched pasta and experimental diets.

\begin{tabular}{|c|c|c|c|c|c|}
\hline Pasta Composition & & & F-Pasta & L-Pasta & P-Pasta \\
\hline Protein $(\%, \mathrm{db})$ & & & 21.2 & 21.2 & 21.5 \\
\hline Total starch $(\%, \mathrm{db})$ & & & 64.4 & 59.1 & 58.5 \\
\hline Total fiber $(\%, \mathrm{db})$ & & & 7.4 & 11.7 & 10.4 \\
\hline Lipids $(\%, \mathrm{db})$ & & & 1.4 & 1.6 & 2.6 \\
\hline Diet ingredients (g) & Casein & SMP & F-Pasta & L-Pasta & P-Pasta \\
\hline Casein & 18.2 & & & & \\
\hline SMP & & 18.2 & & & \\
\hline F-pasta & & & 90 & & \\
\hline L-pasta & & & & 90 & \\
\hline P-pasta & & & & & 90 \\
\hline Native starch (corn) & 64.7 & 64.7 & 1.2 & 1.2 & 1.2 \\
\hline
\end{tabular}


Table 1. Cont.

\begin{tabular}{cccccc}
\hline Diet ingredients (g) & Casein & SMP & F-Pasta & L-Pasta & P-Pasta \\
\hline Cellulose & 6.6 & 6.6 & & & \\
Lipids (soy) & 6 & 6 & 4.3 & 4.3 & 4.3 \\
Minerals & 3.5 & 3.5 & 3.5 & 3.5 & 3.5 \\
Vitamins & 1 & 1 & 1 & 1 & 1 \\
Total diet ingredients & 100 & 100 & 100 & 100 & 100 \\
\hline Diet composition (wt\%) & Casein & SMP & F-Pasta & L-Pasta & P-Pasta \\
\hline Protein (\%)* & 16.4 & 16.4 & 16.7 & 16.8 & 17.0 \\
Carbohydrate (\%) ** & 61.6 & 61.6 & 57.9 & 57.1 & 55.5 \\
Lipid (\%)** & 6 & 6 & 5.4 & 5.6 & 6.4 \\
Energy (Kcal/100 g) & 366 & 366 & 347 & 346 & 348 \\
\hline
\end{tabular}

F-pasta $=$ faba bean-enriched pasta; L-pasta $=$ lentil-enriched pasta; P-pasta $=$ split pea-enriched pasta; $\mathrm{SMP}=$ soluble milk proteins; $\mathrm{wt}_{\mathrm{t}} \%=$ percentage by weight $(\%, \mathrm{wt} / \mathrm{wt}) ; \mathrm{db}=$ dry basis; ${ }^{*}$ Protein content in the diet was calculated from $90 \mathrm{~g}$ of legume-enriched pasta and determined using the Kjeldahl method (NF V 03-050, 1970). ** Carbohydrate contents of legume-enriched pasta diets are calculated from the carbohydrate added to the diet, i.e., native corn starch, and carbohydrate provided from legume-enriched pasta, i.e., total starch, determined while using an enzymatic assay kit (Megazyme, Co. Wicklow, Ireland; AACC method 76-13.01) and total fiber determined according to AOAC 991-42 (for soluble fiber) and AOAC 993-19 (for insoluble fiber) methods. *** Lipid contents of legume-enriched pasta diets were calculated from the lipid added to the diet, i.e., soy oil, and the lipids provided by legume-enriched pasta determined according to French government paper 08-09-1977.

Table 2. Amino acid composition of the diets.

\begin{tabular}{cccccc}
\hline & \multicolumn{5}{c}{ Amino Acid Content (mg/g Protein) } \\
\cline { 2 - 5 } & \multicolumn{2}{c}{ Animal Proteins } & \multicolumn{3}{c}{ Legume-Enriched Pasta } \\
\cline { 2 - 6 } & Casein & SMP & F-Pasta & L-Pasta & P-Pasta \\
\hline Aspartic acid & 66.9 & 113.7 & 97.3 & 102.8 & 109.1 \\
Threonine & 39.5 & 50.5 & 37.0 & 37.2 & 38.3 \\
Serine & 51.2 & 45.1 & 53.1 & 54.9 & 52.4 \\
Glutamic acid & 213.8 & 171.4 & 223.5 & 215.8 & 202.4 \\
Proline & 102.5 & 46.0 & 63.9 & 61.0 & 54.2 \\
Glycine & 17.7 & 19.8 & 42.5 & 41.0 & 43.3 \\
Alanine & 28.9 & 47.8 & 42.0 & 42.0 & 44.3 \\
Valine & 65.9 & 51.4 & 48.2 & 49.7 & 49.5 \\
Sulfur AA & 45.7 & 51.4 & 26.3 & 26.1 & 26.0 \\
Aromatic AA & 88.2 & 72.2 & 74.1 & 81.4 & 83.4 \\
Isoleucine & 48.5 & 50.5 & 43.1 & 45.2 & 45.5 \\
Leucine & 87.7 & 120.3 & 79.1 & 80.3 & 78.9 \\
Lysine & 74.9 & 96.5 & 54.0 & 57.2 & 66.9 \\
Histidine & 26.1 & 20.0 & 26.9 & 25.3 & 25.1 \\
Arginine & 31.9 & 22.6 & 80.0 & 72.8 & 73.9 \\
Tryptophan & 10.6 & 20.7 & 9.0 & 7.5 & 7.1 \\
BCAA & 202.1 & 222.2 & 170.4 & 175.2 & 173.9 \\
EAA & 487.1 & 533.5 & 397.7 & 409.9 & 420.7 \\
\hline
\end{tabular}

${ }^{1}$ Amino acid composition of casein and legume-enriched pasta diets was determined by Agrobio (Rennes, France) according to the method published in Commission Regulation (EC) No 152/2009. ${ }^{2}$ Amino acid composition of SMP was calculated from [49]; F-pasta $=$ faba bean-enriched pasta; L-pasta $=$ lentil-enriched pasta; P-pasta $=$ split pea-enriched pasta; $\mathrm{AA}=$ amino acid; Sulfur AA = methionine + cysteine; Aromatic AA = tyrosine + phenylalanine; $\mathrm{BCAA}=$ branched-chain amino acid; EAA = essential amino acid; $\mathrm{SMP}=$ soluble milk proteins .

\subsection{Animals and Experimental Protocols}

All facilities and procedures were approved by the institution's animal ethics committee 'CEMEAA' (Comité d'Ethique en Matière d'Expérimentation Animale Auvergne; approval No. 5535-20160601140512) and they were used in accordance with the European guidelines for the care and use of laboratory animals (2010-63UE). Our research complies also with the commonly-accepted '3Rs' i.e., Replacement, Reduction, and Refinement. All experiments were conducted in such a way as to avoid animal 
discomfort and minimize animal pain and distress. The study used 43 old (22-month-old) male Wistar rats that were purchased from Janvier (Le Genest-St-Isle, France). The rats were individually housed with free access to water and feed in the research unit's animal facility (approval No. D6334515), and kept under controlled conditions, i.e., a $12 \mathrm{~h}$ light-dark cycle with lights on at 08:00 a.m., and temperature held between $20^{\circ} \mathrm{C}$ and $22^{\circ} \mathrm{C}$.

The rats were randomized into five groups after a week of acclimatization. Two groups were fed a control diet containing casein or SMP ( $n=9$ per group) as sole protein source, and three groups were fed a diet made with F-pasta $(n=9)$, L-pasta $(n=8)$, or P-pasta $(n=8)$ as the sole protein source. All diets were isocaloric and isoproteic (Table 1) and given for six weeks.

Bodyweight and food intake were measured weekly. At the end of the experiment, the rats were anesthetized and sacrificed by exsanguination. The plantaris, soleus, tibialis, gastrocnemius, and quadriceps muscles were quickly removed, weighed, snap-frozen in liquid nitrogen, and stored at $-80{ }^{\circ} \mathrm{C}$. Liver, heart, intestine, and perirenal and subcutaneous adipose tissues were also collected, weighed, snap-frozen in liquid nitrogen, and stored at $-80^{\circ} \mathrm{C}$.

\subsection{Body Composition}

The body composition, i.e., fat and lean mass, of non-anesthetized living rats was measured at the beginning, middle (after three weeks) and end (after six weeks) of the study while using an EchoMRI system (Echo Medical Systems, Houston, TX). The rats were fasted for about $12 \mathrm{~h}$ before the measurement, but had unlimited access to drinking water. Results are expressed in lean mass gain and fat mass gain. The lean mass gain was calculated as the difference in lean mass between the beginning and the end of the study as a ratio of initial lean mass of the old rats.

\subsection{Dietary Protein Quality Indexes}

For the last four days of the experiment, the rats were placed in metabolic cages with facilities for separating and collecting urine and fecal matter. Urine and feces were collected to quantify excreted nitrogen by the Dumas method [50] at Institut UniLaSalle (Beauvais, France) and to evaluate protein quality parameters. Nitrogen balance, apparent and true protein digestibility, net protein utilization, and biological value were calculated according to the following equations (Equations (1)-(5)); [51]:

$$
\begin{gathered}
\mathrm{NB}(\mathrm{g})=\mathrm{NI}-(\mathrm{FN}+\mathrm{UN}) \\
\mathrm{AD}(\%)=\frac{\mathrm{NI}-\mathrm{FN}}{\mathrm{NI}} \times 100 \\
\mathrm{TD}(\%)=\frac{\mathrm{NI}-(\mathrm{FN}-\mathrm{EFN})}{\mathrm{NI}} \times 100 \\
\mathrm{NPU}(\%)=\frac{\mathrm{NI}-(\mathrm{FN}+\mathrm{UN}-\mathrm{EFN}-\mathrm{EUN})}{\mathrm{NI}} \times 100 \\
\mathrm{BV}(\%)=\frac{\mathrm{NPU}}{\mathrm{TD}} \times 100
\end{gathered}
$$

where NB is nitrogen balance, NI is nitrogen intake, FN is fecal nitrogen, $\mathrm{UN}$ is urinary nitrogen, $\mathrm{AD}$ is apparent digestibility, TD is true digestibility, EFN is endogenous fecal nitrogen, EUN is endogenous urinary nitrogen, NPU is net protein utilization, and BV is biological value.

Fecal and urinary endogenous nitrogen excretions were deduced from a group of old rats that received a nitrogen-free diet during the metabolic cage period.

\subsection{Biochemical Analyses}

Blood glucose level was measured using a Konelab 20 chemical analyzer (Thermo Scientific, MA). Blood insulin level was measured while using an ELISA kit (PromoKine, France) according to the manufacturer's instructions. 


\subsection{Tissue Protein Extraction and Content}

The total proteins were extracted from $50 \mathrm{mg}$ of plantaris, gastrocnemius and liver in $500 \mu \mathrm{L}$ of SET extraction buffer (0.25 M Sucrose, 2 mM EDTA, $10 \mathrm{mM}$ Tris, $\mathrm{pH}$ 7.4). After homogenization with Mini Beadbeater ${ }^{\circledR}$ (BioSpec Products, Bartlesville, OK, USA), the homogenate was removed, transferred to a hemolysis tube, and then sonicated three times for $10 \mathrm{~s}$ at $70 \%$ of maximal power (Vibracell 75185, VWR International, Radnor, PA, USA). A colorimetric protein assay was then carried out after protein extraction. The samples and a standard range, made from bovine serum albumin (BSA), were deposited on a 96-well microplate. A bicinchoninic acid reagent from the Micro BCA protein assay kit (Thermo Fischer Scientific, Waltham, MA, USA) was also added. Protein concentration was estimated as BSA equivalent and measured at a 562-nm wavelength while using a microplate reader (Microplate Spectrophotometer Epoch Biotek, Winooski, VT, USA) after incubation for $1 \mathrm{~h}$ at $37^{\circ} \mathrm{C}$ without agitation. The total protein content in muscle and liver was expressed in mg of proteins. The efficiency of tissue protein anabolism, defined as the ratio of tissue protein content relative to cumulative protein intake over the six weeks diet period, was also calculated as per Mantha et al. [52].

\subsection{Protein Synthesis Rate in Plantaris Muscle}

We measured absolute synthesis rate (ASR) of proteins in plantaris muscle using the flooding dose method to evaluate skeletal muscle protein synthesis, as previously described [53]. Briefly, after overnight food deprivation, the rats were infused with 50\% excess mol, $300 \mu \mathrm{M} / 100 \mathrm{~g}$ L(1-13C)valine (Eurisotop Saint-Aubin, France). The tracer uptake time was $50 \mathrm{~min}$. A $50 \mathrm{mg}$ sample of plantaris muscle was used for analysis. Proteins were hydrolyzed $\left(6 \mathrm{~N} \mathrm{HCl}, 110{ }^{\circ} \mathrm{C}, 24 \mathrm{~h}\right)$ then the amino acids were derivatized. L(1-13C)valine enrichment was measured in hydrolyzed proteins while using gas chromatography-combustion-isotope ratio mass spectrometry (Gas System; Fisons Instruments, VG Isotech, Middlewich, UK). L(1-13C)valine enrichment in tissue fluid was evaluated using gas chromatography-mass spectrometry (Hewlett-Packard 5971A; Hewlett-Packard Co., Palo Alto, CA, USA). ASR was calculated according to fractional synthesis rate [53] and total muscle protein content using the following equation (Equation (6)):

$$
\operatorname{ASR}(\mathrm{mg} / \mathrm{h})=(\mathrm{Ei} \times 100) \times \mathrm{P} \times \mathrm{M} /(\mathrm{Ep} \times \mathrm{t})
$$

where Ei is enrichment as atom percent excess of $\mathrm{L}(1-13 \mathrm{C})$ valine derived from valine from proteins at time $\mathrm{t}$ (minus basal enrichment), Ep is mean enrichment in the precursor pool (tissue fluid $\mathrm{L}(1-13 \mathrm{C})$ valine), $\mathrm{t}$ is uptake time in hours, $\mathrm{P}$ is protein content in muscle in $\mathrm{mg}$ per $\mathrm{mg}$ of muscle, and $\mathrm{M}$ is muscle mass in $\mathrm{mg}$. The data are expressed in $\mathrm{mg}$ of total protein synthesis per hour.

\subsection{Statistical Analysis}

Analysis of variance (ANOVA) and Fisher's protected least significant difference (PLSD) test were used to determine significant differences between the groups. Differences were considered to be significant at $p<0.05$. Statistical data analysis was performed using StatView ${ }^{\circledR}$ software (SAS, Inc. Intitute, Release 5, 1992-82, Cary, NC, USA).

\section{Results}

\subsection{Diet Compositions}

All of the diets were isocaloric and isoproteic (Table 1). On a whole, the legume-enriched pasta had comparable EAA compositions, except for aromatic amino acid, branched-chain amino acid, and lysine contents that were slightly higher in L-pasta and P-pasta than in F-pasta (Table 2). However, proteins from legume-enriched pasta were characterized by a different amino acid composition as compared to animal-protein diets. Casein and SMP diets had a two-fold higher sulfur amino acid content and 1.2-fold higher branched-chain amino acid content than legume-enriched pasta. Legume-enriched 
pasta had two-fold higher glycine content and three-fold higher arginine content than casein and SMP diets.

\subsection{Body Composition}

Bodyweight, fat mass, and lean mass were not statistically different between diet groups at each point of time i.e., the beginning, the middle, and the end of the experiment. For each diet group, there were no statistical differences with time for bodyweight, fat mass, and lean mass, respectively (Figure 1). Bodyweight, fat mass gain, and lean mass gain were higher in rats that were fed SMP and legume-enriched pasta as compared with rats fed casein (Table 3). In old rats, lean mass was increased under all the diets (by $3.3 \%-5.1 \%$ increase), except for the casein diet $(0.3 \%)$, but without statistically significant between-group difference $(p=0.15)$. The increase in fat mass tended to be higher in rats fed SMP $(14.9 \pm 7.8 \%)$ than rats fed F-pasta $(3.6 \pm 3.0 \%)$ and L-pasta $(1.2 \pm 6.4 \%)$ diets $(p=0.13$ and $p=0.08$, respectively), but was significantly higher than rats fed casein $(-8.7 \pm 4.3 \%)$ and P-pasta $(-3.6 \pm 3.4 \%)$ diets $(p<0.05)$. As a result, after six-week diets, the bodyweight of old rats was increased in legume-enriched pasta and SMP groups, but decreased in the casein group $(p<0.05)$ (Table 3$)$.
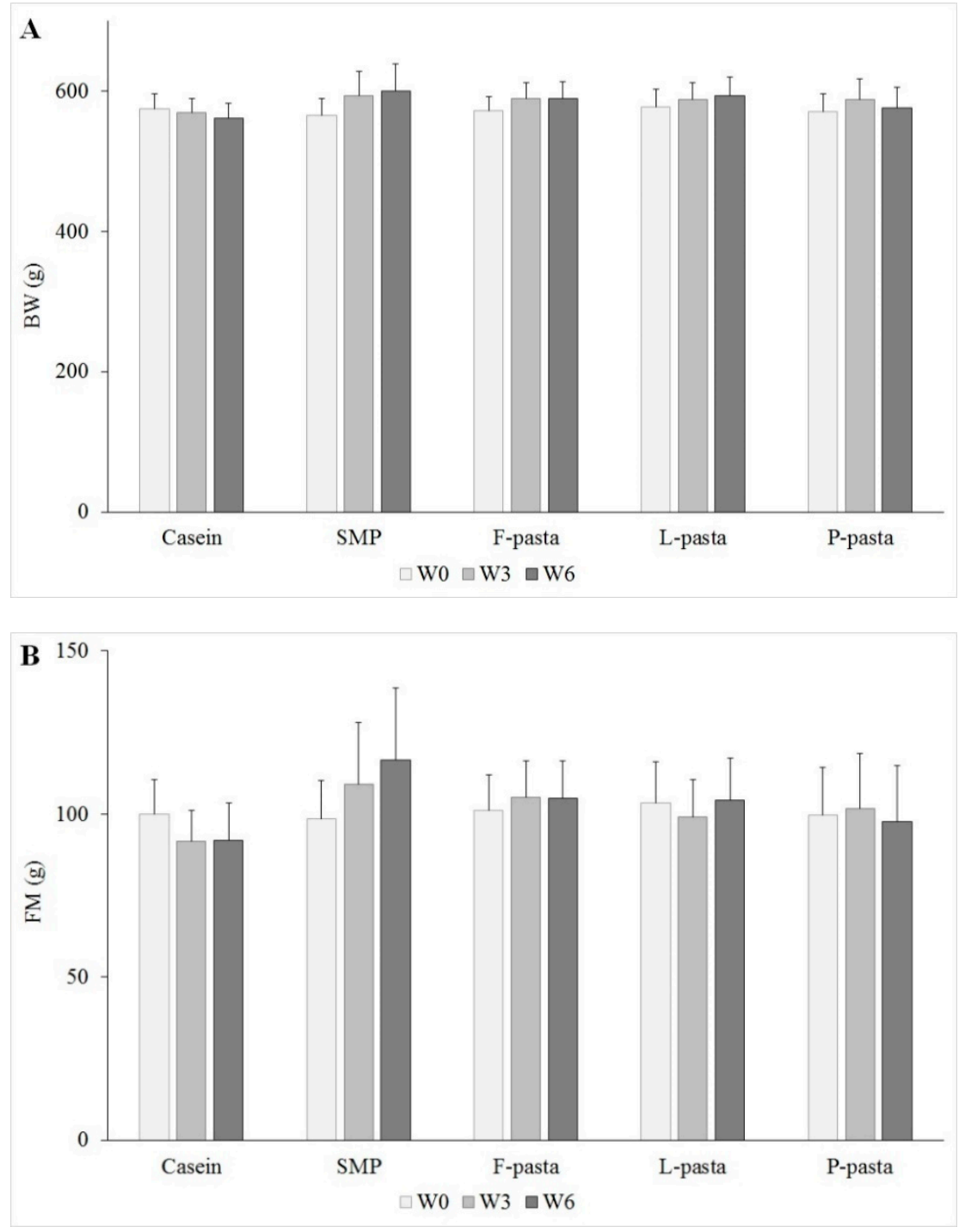

Figure 1. Cont. 


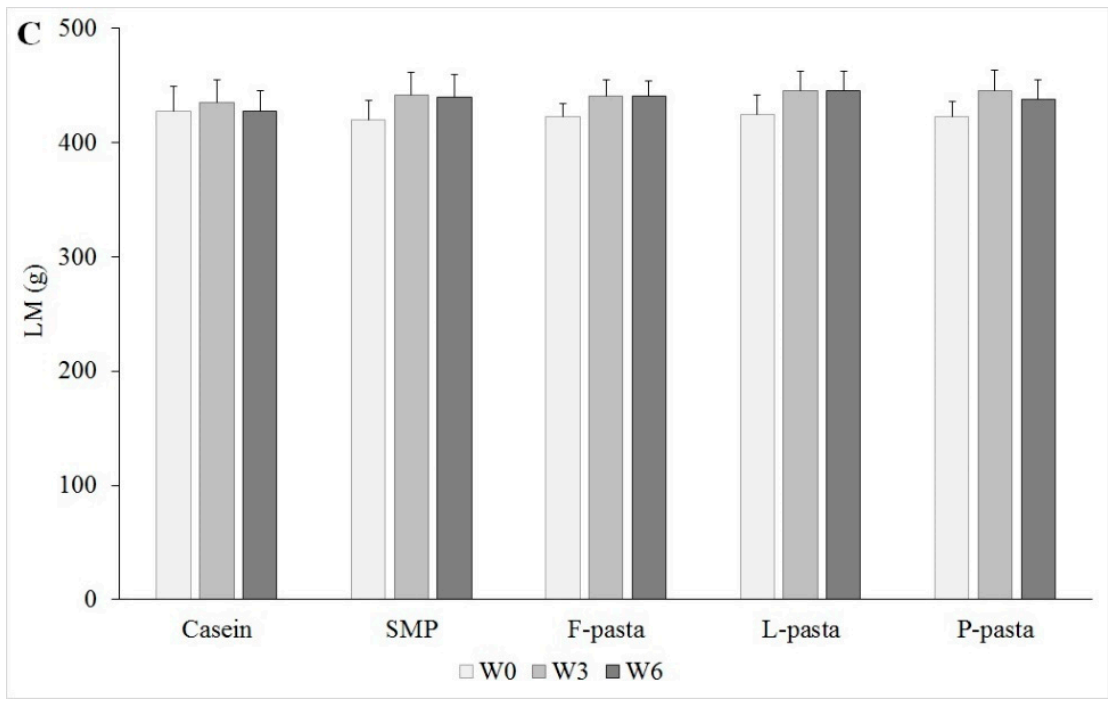

Figure 1. Bodyweight (A), fat mass (B), and lean mass (C) variations during the time. The results are expressed as means \pm SEM; Means with different letters are significantly different $(p<0.05)$. W0, W3, and $\mathrm{W} 6$ = the beginning, the middle, and the end of the experiment, respectively; $\mathrm{BW}=$ bodyweight; $\mathrm{FM}=$ fat mass; $\mathrm{LM}=$ lean mass; F-pasta = faba bean-enriched pasta; $\mathrm{L}$-pasta = lentil-enriched pasta; P-pasta $=$ split pea-enriched pasta; and, $\mathrm{SMP}=$ soluble milk proteins.

Table 3. Body composition of old rats after six weeks of diet.

\begin{tabular}{cccccc}
\hline Diets & Casein & SMP & F-Pasta & L-Pasta & P-Pasta \\
\hline$\Delta \mathrm{BW}(\%)$ & $-2.3 \pm 1.8^{\mathrm{b}}$ & $5.6 \pm 2.6^{\mathrm{a}}$ & $2.9 \pm 1.4^{\mathrm{a}}$ & $2.7 \pm 1.5^{\mathrm{a}}$ & $0.9 \pm 0.8^{\mathrm{ab}}$ \\
$\Delta \mathrm{FM}(\%)$ & $-8.7 \pm 4.3^{\mathrm{b}}$ & $14.9 \pm 7.8^{\mathrm{a}}$ & $3.6 \pm 3.0^{\mathrm{ab}}$ & $1.2 \pm 6.4^{\mathrm{ab}}$ & $-3.6 \pm 3.4^{\mathrm{b}}$ \\
$\Delta \mathrm{LM}(\%)$ & $0.3 \pm 1.7$ & $4.5 \pm 1.3$ & $4.4 \pm 1.6$ & $5.1 \pm 1.0$ & $3.3 \pm 1.3$ \\
\hline
\end{tabular}

Results are expressed as means \pm SEM. Means sharing the same letters i.e., ${ }^{a}$ or ${ }^{b}$, within a line are not significantly different $(p>0.05)$. F-pasta $=$ faba bean-enriched pasta; L-pasta $=$ lentil-enriched pasta; $P$-pasta $=$ split pea-enriched pasta; $\mathrm{SMP}=$ soluble milk proteins; $\Delta \mathrm{BW}=$ bodyweight gain; $\Delta \mathrm{FM}=$ fat mass gain; $\Delta \mathrm{LM}=$ lean mass gain .

\subsection{Evaluation of Dietary Protein Quality}

Table 4 reports protein quality indexes. Food intake calculated during the six-week period was not different between groups (data not shown). Fecal nitrogen content-to-nitrogen intake ratio was 1.4-fold higher in old rats that were fed F-pasta and P-pasta and two-fold higher in old rats fed L-pasta when compared to rats fed casein and SMP diets $(p<0.001)$. The urinary nitrogen content-to-nitrogen intake ratio was similar between rats fed SMP and L-pasta diets, but $29 \%$ lower than in rats fed casein and F-pasta diets $(p<0.05)$ and slightly lower than in rats fed P-pasta $(-19 \%, p=0.14)$.

Table 4. Dietary protein quality evaluation using the nitrogen balance method in old rats after 6 weeks of diet.

\begin{tabular}{cccccc}
\hline Diets & Casein & SMP & F-Pasta & L-Pasta & P-Pasta \\
\hline FN/NI & $0.11 \pm 0.01^{\mathrm{c}}$ & $0.09 \pm 0.01^{\mathrm{c}}$ & $0.14 \pm 0.01^{\mathrm{b}}$ & $0.21 \pm 0.02^{\mathrm{a}}$ & $0.14 \pm 0.01^{\mathrm{b}}$ \\
UN/NI & $0.67 \pm 0.06^{\mathrm{a}}$ & $0.47 \pm 0.04^{\mathrm{b}}$ & $0.65 \pm 0.05^{\mathrm{a}}$ & $0.47 \pm 0.04^{\mathrm{b}}$ & $0.58 \pm 0.05^{\mathrm{ab}}$ \\
NB (g) & $0.43 \pm 0.11^{\mathrm{b}}$ & $0.79 \pm 0.10^{\mathrm{a}}$ & $0.42 \pm 0.08^{\mathrm{b}}$ & $0.68 \pm 0.09^{\mathrm{ab}}$ & $0.53 \pm 0.09^{\mathrm{ab}}$ \\
AD (\%) & $88.83 \pm 0.59^{\mathrm{a}}$ & $91.26 \pm 0.70^{\mathrm{a}}$ & $86.15 \pm 0.97^{\mathrm{b}}$ & $79.19 \pm 1.68^{\mathrm{c}}$ & $86.13 \pm 0.67^{\mathrm{b}}$ \\
TD (\%) & $97.61 \pm 0.75^{\mathrm{a}}$ & $98.67 \pm 0.74^{\mathrm{a}}$ & $92.85 \pm 0.97^{\mathrm{b}}$ & $85.44 \pm 1.90^{\mathrm{c}}$ & $93.02 \pm 0.84^{\mathrm{b}}$ \\
NPU (\%) & $45.44 \pm 5.62^{\mathrm{b}}$ & $63.21 \pm 4.15^{\mathrm{a}}$ & $39.23 \pm 4.24^{\mathrm{b}}$ & $48.67 \pm 4.72^{\mathrm{b}}$ & $46.16 \pm 5.27^{\mathrm{b}}$ \\
BV (\%) & $46.60 \pm 5.69^{\mathrm{b}}$ & $63.92 \pm 3.90^{\mathrm{a}}$ & $42.56 \pm 4.99^{\mathrm{b}}$ & $56.69 \pm 4.94^{\mathrm{ab}}$ & $49.72 \pm 5.81^{\mathrm{ab}}$ \\
\hline
\end{tabular}

Results are given as means \pm SEM. Means sharing the same letters i.e., ${ }^{a}, \mathrm{~b}$ or ${ }^{\mathrm{c}}$, within a line are not significantly different $(p>0.05)$. F-pasta $=$ faba bean-enriched pasta; L-pasta $=$ lentil-enriched pasta; P-pasta $=$ split pea-enriched pasta; $\mathrm{SMP}=$ soluble milk proteins; $\mathrm{NI}=$ nitrogen intake; $\mathrm{FN}$ = fecal nitrogen; $\mathrm{UN}=$ urinary nitrogen; $\mathrm{NB}$ = nitrogen balance; $\mathrm{AD}=$ apparent digestibility; $\mathrm{TD}$ = true digestibility; $\mathrm{NPU}=$ net protein utilization; $\mathrm{BV}$ = biological value. 
Nitrogen balance, i.e., the difference between nitrogen intake and nitrogen losses when considering urinary and fecal losses, was higher in rats that were fed the SMP diet as compared to casein $(0.79 \pm 0.10 \mathrm{~g}$ vs. $0.43 \pm 0.11 \mathrm{~g}$, respectively; $p<0.01$ ). The nitrogen balance was in the same range in rats fed either casein or legume-enriched pasta. Nitrogen balance was not significantly different between rats fed SMP diet when compared to L-pasta $(0.68 \pm 0.09 \mathrm{~g})$ and P-pasta $(0.53 \pm 0.09 \mathrm{~g} ; p=0.06)$.

Apparent digestibility considers all of the digestive processes involving protein digestion, including endogenous nitrogen losses. Apparent digestibility was similar between SMP and casein groups and $5 \%$ higher than in the F-pasta and P-pasta groups and 14\% higher than in the L-pasta group $(p<0.001)$. True digestibility considers the specific digestion of dietary protein by subtracting endogenous nitrogen losses. Like for apparent digestibility, true digestibility was significantly higher in rats that were fed animal-source proteins, i.e., casein and SMP, than legume-enriched pasta, especially L-pasta $(p<0.001)$.

Net protein utilization (NPU) is the ratio of retained nitrogen to ingested nitrogen. After six weeks of diet, NPU was 39\% higher in rats that were fed SMP diet as compared to casein diet $(p=0.01)$. Old rats fed legume-enriched pasta had a similar NPU to the casein group but a lower NPU than the SMP group $(p<0.05)$. Biological value $(\mathrm{BV})$ is the ratio of retained nitrogen to absorbed nitrogen. The BV of SMP $(63.9 \pm 3.9 \%)$ was $37 \%$ higher than the BV of casein $(46.6 \pm 5.7 \% ; p=0.01)$. Overall, legume-enriched pasta had a similar BV to casein. However, F-pasta had a significantly lower BV than SMP $(42.6 \pm 5.0 \% ; p<0.01)$, and P-pasta tended to have a lower BV than SMP $(49.7 \pm 5.8 \% ; p=0.06)$, whereas L-pasta had a similar BV to SMP $(56.7 \pm 4.9 \%)$.

\subsection{Biochemical Analyses}

Table 5 provides biochemical analyses. Fasting insulin and glucose levels were not statistically different between groups. Note that, the fasting insulin level tended to be higher in SMP group as compared to legume enriched pasta, i.e., L- and P-pasta groups, and casein group $(p=0.07)$.

Table 5. Fasting insulin and glucose levels in old rats after 6 weeks of diet.

\begin{tabular}{cccccc}
\hline Diets & Casein & SMP & F-Pasta & L-Pasta & P-Pasta \\
\hline Insulin $(\mathrm{ng} / \mathrm{mL})$ & $0.55 \pm 0.06$ & $0.85 \pm 0.19$ & $0.74 \pm 0.12$ & $0.50 \pm 0.04$ & $0.51 \pm 0.06$ \\
Glucose $(\mathrm{g} / \mathrm{L})$ & $1.29 \pm 0.06$ & $1.37 \pm 0.05$ & $1.24 \pm 0.06$ & $1.26 \pm 0.08$ & $1.26 \pm 0.06$ \\
\hline
\end{tabular}

Results are given as means \pm SEM. Means with different letters within a line are significantly different $(p<0.05)$. F-pasta = faba bean-enriched pasta; L-pasta = lentil-enriched pasta; P-pasta = split pea-enriched pasta; SMP = soluble milk proteins.

\subsection{Tissue Weight, Protein Content, and Protein Anabolism Efficiency}

Table 6 reports tissue weights. As expected, total skeletal muscle mass (the sum of plantaris, soleus, tibialis, gastrocnemius, and quadriceps weights) tended to be higher in old rats fed SMP than those fed casein $(p=0.07)$. Rats that were fed legume-enriched pasta had similar skeletal muscle mass to rats fed the casein diet and rats fed L-pasta and P-pasta even had similar skeletal muscle mass to rats fed the SMP diet. For example, the plantaris muscle mass was higher in the SMP group $(428 \pm 23 \mathrm{mg})$ when compared to the casein group ( $341 \pm 28 \mathrm{mg}$ ) and F-pasta group ( $329 \pm 35 \mathrm{mg})$, but was similar in the SMP group as compared to the P-pasta (366 $\pm 19 \mathrm{mg})$ and L-pasta (390 $\pm 17 \mathrm{mg})$ groups $(p=0.07)$. There were no significant between-group differences in liver weight $(p=0.57)$, adipose tissue weight (the sum of subcutaneous and perirenal adipose tissues) $(p=0.80)$, and intestine weight $(p=0.98)$.

Tissue protein contents and protein anabolism efficiency were determined for plantaris and gastrocnemius muscles and for liver (Table 7). The protein content in plantaris muscle was higher in the SMP group $(50.33 \pm 4.66 \mathrm{mg}$ proteins) as compared to rats fed casein $(32.43 \pm 4.24 \mathrm{mg}$ proteins) and F-pasta group (35.97 $\pm 4.58 \mathrm{mg}$ proteins) and similar between the P-pasta group $(38.57 \pm 2.99 \mathrm{mg}$ proteins) and the L-pasta group (46.03 $\pm 6.57 \mathrm{mg}$ proteins). Protein anabolism efficiency in plantaris and gastrocnemius muscles was similar between rats that were fed legume-enriched pasta and fed casein or $\operatorname{SMP}(p>0.05)$. 
Table 6. Tissue weights in old rats after six weeks of diet.

\begin{tabular}{|c|c|c|c|c|c|}
\hline $\begin{array}{c}\text { Diets } \\
\text { Tissues }\end{array}$ & Casein & SMP & F-Pasta & L-Pasta & P-Pasta \\
\hline Initial BW & $576 \pm 21$ & $566 \pm 24$ & $573 \pm 20$ & $578 \pm 25$ & $571 \pm 26$ \\
\hline Final BW & $562 \pm 21$ & $600 \pm 39$ & $590 \pm 24$ & $594 \pm 26$ & $577 \pm 29$ \\
\hline Plantaris (mg) & $341 \pm 28^{b}$ & $428 \pm 23^{a}$ & $329 \pm 35^{b}$ & $390 \pm 17^{a b}$ & $366 \pm 19 a b$ \\
\hline Soleus (mg) & $207 \pm 9$ & $249 \pm 10$ & $218 \pm 19$ & $233 \pm 14$ & $220 \pm 11$ \\
\hline Tibialis (mg) & $595 \pm 51^{c}$ & $773 \pm 35^{a}$ & $601 \pm 67 b c$ & $745 \pm 49 \mathrm{ab}$ & $703 \pm 48^{a b c}$ \\
\hline Gastrocnemius (g) & $1.6 \pm 0.1^{b}$ & $2.0 \pm 0.1^{a}$ & $1.6 \pm 0.2^{b}$ & $1.9 \pm 0.1^{\mathrm{ab}}$ & $1.8 \pm 0.1^{\mathrm{ab}}$ \\
\hline Quadriceps (g) & $2.9 \pm 0.2^{c}$ & $3.7 \pm 0.2^{\mathrm{a}}$ & $3.1 \pm 0.3^{b c}$ & $3.6 \pm 0.1 \mathrm{ab}$ & $3.2 \pm 0.2 \mathrm{abc}$ \\
\hline TMM (g) & $11.4 \pm 0.6^{b}$ & $14.3 \pm 0.7^{\mathrm{a}}$ & $11.7 \pm 1.2^{b}$ & $13.5 \pm 0.5^{\mathrm{ab}}$ & $12.7 \pm 0.8^{\mathrm{ab}}$ \\
\hline Heart (g) & $1.60 \pm 0.05$ & $1.78 \pm 0.04$ & $1.67 \pm 0.05$ & $1.75 \pm 0.07$ & $1.66 \pm 0.05$ \\
\hline Liver (g) & $11.9 \pm 0.5$ & $12.7 \pm 0.7$ & $13.1 \pm 0.7$ & $12.4 \pm 0.8$ & $13.2 \pm 0.4$ \\
\hline AT (g) & $17.2 \pm 2.2$ & $21.9 \pm 4.4$ & $20.5 \pm 2.7$ & $18.9 \pm 2.4$ & $18.2 \pm 2.4$ \\
\hline Intestine (g) & $5.5 \pm 0.4$ & $5.6 \pm 0.4$ & $5.3 \pm 0.3$ & $5.4 \pm 0.3$ & $5.5 \pm 0.4$ \\
\hline
\end{tabular}

Results are given as means \pm SEM. Means sharing the same letters i.e., ${ }^{\mathrm{a}, \mathrm{b}}$ or $^{\mathrm{c}}$, within a line are not significantly different $(p>0.05)$. BW = bodyweight; F-pasta $=$ faba bean-enriched pasta; L-pasta $=$ lentil-enriched pasta; $P$-pasta $=$ split pea-enriched pasta; $\mathrm{SMP}=$ soluble milk proteins; $\mathrm{TMM}=$ total skeletal muscle mass, $\mathrm{AT}=$ adipose tissue (the sum of perirenal and subcutaneous adipose tissues).

Table 7. Tissue protein content and protein anabolism efficiency in old rats after six weeks of diet.

\begin{tabular}{|c|c|c|c|c|c|}
\hline & Casein & SMP & F-Pasta & L-Pasta & P-Pasta \\
\hline Total protein content, $\mathrm{mg}$ & $230.7 \pm 19.4$ & $310.2 \pm 33.8$ & $252.2 \pm 55.8$ & $273.3 \pm 18.7$ & $272.8 \pm 17.9$ \\
\hline \multicolumn{6}{|l|}{ Plantaris } \\
\hline Total protein content, mg & $32.43 \pm 4.24^{b}$ & $50.33 \pm 4.66^{\mathrm{a}}$ & $35.97 \pm 4.58^{b}$ & $46.03 \pm 6.57 \mathrm{ab}$ & $38.57 \pm 2.99 a b$ \\
\hline Total protein content, mg & $2452 \pm 105^{b}$ & $2578 \pm 182^{b}$ & $2900 \pm 142^{a b}$ & $2717 \pm 287^{\mathrm{ab}}$ & $3117 \pm 117^{\mathrm{a}}$ \\
\hline Protein anabolism efficiency (\%) & $2.00 \pm 0.16^{b}$ & $1.84 \pm 0.11^{b}$ & $2.18 \pm 0.11^{a b}$ & $1.99 \pm 0.17^{b}$ & $2.40 \pm 0.09^{a}$ \\
\hline
\end{tabular}

Results are given as means \pm SEM. Means sharing the same letters i.e., ${ }^{a}$ or ${ }^{b}$, within a line are not significantly different $(p>0.05)$. F-pasta $=$ faba bean-enriched pasta; L-pasta $=$ lentil-enriched pasta; P-pasta $=$ split pea-enriched pasta; SMP = soluble milk proteins.

The liver protein content was higher in the P-pasta group $(3.12 \pm 0.12 \mathrm{~g})$ than in the casein and SMP groups $(2.45 \pm 0.11$ and $2.58 \pm 0.18 \mathrm{~g})$. Consequently, liver protein anabolism efficiency was higher in the P-pasta group $(2.4 \pm 0.1 \%)$ than the casein and SMP groups $(2.0 \pm 0.2$ and $1.8 \pm 0.1 \%$, respectively).

\subsection{Absolute Protein Synthesis Rate in Plantaris Muscle}

ASR was measured in plantaris muscle (Figure 2). As expected, ASR was significantly higher (+41\%) in the SMP group when compared to the casein group $(0.138 \pm 0.011 \mathrm{mg} / \mathrm{h}$ vs. $0.098 \pm 0.012 \mathrm{mg} / \mathrm{h}$, respectively; $p$ < 0.05). Moreover, ASR in all legume-enriched pasta groups, i.e., F-pasta (0.094 $\pm 0.012 \mathrm{mg} / \mathrm{h}), \mathrm{L}-$ pasta $(0.098 \pm 0.012 \mathrm{mg} / \mathrm{h})$ and P-pasta $(0.084 \pm 0.008 \mathrm{mg} / \mathrm{h})$, was similar to the casein group, but significantly lower, by $29 \%-39 \%$, than for SMP $(p<0.05)$. 


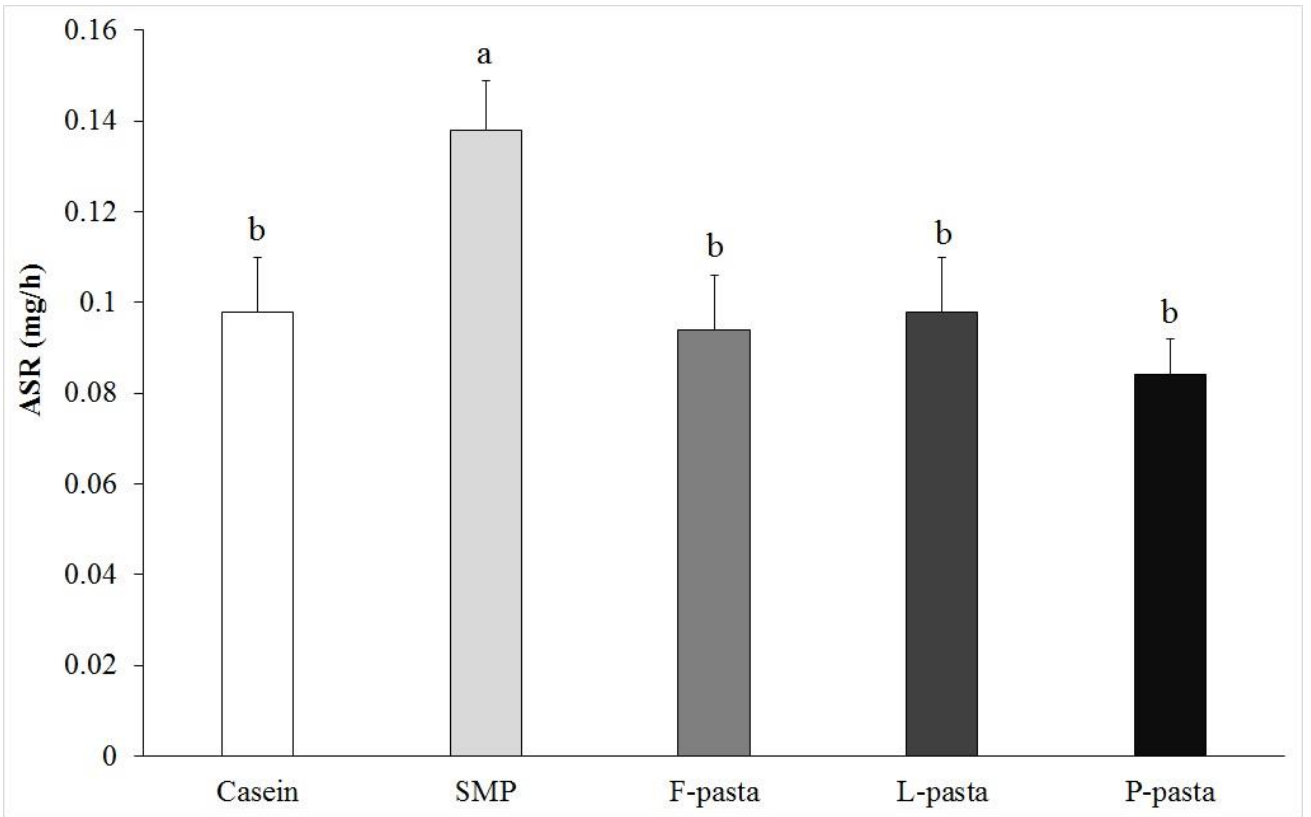

Figure 2. Protein synthesis rate in plantaris muscle in old rats after six weeks of diet; results are expressed as means \pm SEM; means with the same letters are not significantly different $(p>0.05)$. ASR = absolute synthesis rate; F-pasta $=$ faba bean-enriched pasta; L-pasta = lentil-enriched pasta; $\mathrm{P}$-pasta $=$ split pea-enriched pasta $; \mathrm{SMP}=$ soluble milk proteins.

\section{Discussion}

The aim of this study was to evaluate the protein quality of wheat pasta enriched with faba bean or lentil or split pea flour and the impact of their intake on protein retention and metabolism in old rats as compared to dietary animal proteins, i.e., casein and SMP. The nutritional value of proteins is dependent on their amino acid composition and how readily they can be digested, absorbed, and incorporated into body proteins [54]. As expected, casein and SMP had higher apparent and true protein digestibility than legume-enriched pasta, especially the L-pasta. Sarwar et al. [55] noted that the presence of residual anti-nutritional factors, i.e., trypsin inhibitors, lectins, amylase inhibitors, in cooked pulses could interfere with protein digestion and increase endogenous protein excretion, particularly proteases, when compared to animal proteins [56]. In old rats, this could result in increased fecal nitrogen excretion and lower protein digestibility for legume-enriched pasta as compared to animal protein-based diets. Here, we found that protein digestibility differed between source-pulses. Specifically, the protein digestibility of F- and P-pasta was higher than that of L-pasta. Accordingly, the residual activity of trypsin inhibitors was 5\% and 21\% higher in L-pasta than in F- and P-pasta, respectively [57]. Protein digestibility might also be affected by protein aggregation through steric hindrance or even by protein covalent crosslinking, which limits proteolytic enzyme access and action with and towards peptide bonds [58]. L-pasta contained $11 \%$ and $14 \%$ higher proportions of covalently-linked proteins, i.e., disulfide-bonded proteins rather than weakly-linked proteins, than Fand P-pasta, respectively [57].

Higher protein digestibility promotes a higher amount of amino acid available for absorption and, thus, greater nutritional value [59]. NPU was equivalent between old rats fed legume-enriched pasta or casein despite a lower digestibility of legume-enriched pasta proteins. Urinary nitrogen excretion in old rats was lower after L-pasta intake and, to a lower extent, after P- and F-pasta intake than casein, leading to an equivalent nitrogen retention in the body. This contrasts with Löhrke et al. [60], who reported a higher urinary nitrogen excretion and increased plasma level of urea in pigs in response to dietary soybean protein isolate when compared to casein. Laleg et al. [46] demonstrated that protein utilization increased by $75 \%$ in young rats fed wheat pasta enriched with $35 \%$ faba bean 
flour as compared to an isoproteic wheat pasta enriched with gluten, but remained $9 \%$ lower than in rats fed casein. Mixed wheat-legume pasta has a more balanced amino acid composition when compared to wheat protein alone, i.e., gluten-enriched pasta, which could explain the higher protein utilization [46]. Furthermore, contrary to what was shown with the $35 \%$ faba bean pasta [46], here we observed equivalent protein utilization between legume-enriched pasta and casein diets when the legume enrichment level in the pasta increased up to $62-79 \%$. The essential amino acid composition of the legume-enriched pasta used here was closer to casein and to rat needs according to National Research Council [61] than for the 35\% faba bean pasta [46]. However, here, the measured net protein utilization was lower in old rats fed casein or legume-enriched pasta than SMP. Note that this difference could be explained not only by the essential amino acid composition, in particular a higher leucine content (+51\% as compared to legume-enriched pasta), but also to the rapid assimilation of SMP [62].

Fat mass gain and lean mass gain, in particular muscle mass change, were equivalent in these old rats that were fed the different legume-enriched pasta after six weeks of diets, regardless of the legume flour used. Therefore, there was no effect of legume type and, more precisely, of legume/wheat protein ratio on body composition in old rats. In addition, old rats fed legume-enriched pasta had comparable lean mass gain to rats fed casein or SMP, regardless of pulse source. Furthermore, the weight and protein content of plantaris and gastrocnemius muscles were grossly similar between the rat groups fed legume-enriched pasta and the casein and SMP groups. Several studies have evaluated the effect of dietary protein sources on protein metabolism, but were generally done in young rats. Wróblewska et al. [35] evaluated the body composition of young rats that were fed a commercial soy protein preparation and demonstrated that they had a lower bodyweight, fat and lean mass gain than rats fed a whey protein preparation. Martínez and Larralde $[18,19]$ demonstrated that feeding young rats with diets containing raw legume, i.e., Vicia faba, induced a significant decrease in muscle mass compared to casein. However, the authors did not find any difference in myofibrillar protein breakdown between rats receiving raw legume and casein. They suggested that the decrease in muscle mass could be explained by a decrease in muscle protein synthesis in rats that were fed raw legume due to the presence of antinutritional compounds, like trypsin inhibitors in raw Vicia faba that reduce protein digestibility. Here, the manufacturing process used, including cooking, significantly decreased the activity of trypsin inhibitors as compared to raw flours and resulted in a drastic reduction of trypsin inhibitors in the legume-enriched pasta, i.e., a residual activity of $3 \%-5 \%$ in comparison to the raw legume flour [57]. Alonso et al. [25] found a lower muscle mass and muscle protein content in young rats fed seed peas deficient in certain essential amino acids, even if extruded and cooked to reduce antinutritional factor content, than after casein intake. Taken together, the data that are presented here showed that mixed wheat-legume pasta intake promoted a similar muscle gain to casein intake and even SMP intake (for L- and P-pasta) in old rats. Mixing wheat and legume flour in pasta also resulted in more efficient muscle mass maintenance than when using legumes $[18,19,25]$. Combining wheat and legume proteins in pasta allowed for a needs-balanced amino acid intake, which is vital for maintaining or even increasing muscle mass, in particular in old rats. The capacity of legume-enriched pasta to increase lean mass, in particular muscle mass, could be beneficial for older people that are exposed to sarcopenia.

The changes that were observed for protein synthesis rates in plantaris muscle in old rats were relatively in line with changes in muscle mass and muscle protein content. Muscle mass and protein content tended to be higher in the SMP group as compared to the casein and F-pasta groups, although not compared to L- and P-pasta groups. We suggest that L- and P-pasta intake could enhance postprandial muscle protein anabolism in old rats, which would translate into muscle protein accretion and increased muscle mass. Several studies have compared the influence of plant-based proteins and animal-based proteins on muscle protein synthesis. In young rats, the protein synthesis rate was lower in gastrocnemius muscle [21] after raw faba bean intake than after milk protein intake. In addition, young rats had a lower muscle protein synthesis rate when fed cooked beans and lentils when compared to casein [24], although the protein synthesis rate was higher in the large and small 
intestine $[24,26]$. In older humans, Yang et al. [37] showed that the muscle protein synthesis rate was lower in people fed soy protein isolate than those fed whey protein isolate in both rested and post-exercise conditions. A more recent study demonstrated that the muscle protein synthesis rate in older people was lower after consumption of $35 \mathrm{~g}$ of wheat protein hydrolysate as compared to an equal amount of casein [38].

Taken together, these studies showed that, in young as well as in old individuals, the muscle protein synthesis rate was higher after milk protein intake when compared to legume or wheat protein consumed alone. Interestingly, we clearly demonstrated here that the muscle protein synthesis rate was not different in old rats fed casein when compared to counterparts fed a mixed wheat-legume pasta, although it remained lower than in animals that were fed SMP. The high anabolic effect of SMP (rapidly-digested and leucine-rich protein; [63-65]) could explain the ability of this protein to enhance body protein retention and muscle protein synthesis in old rats. Note that this high anabolic effect of SMP resulted in a slight increase in muscle mass together with an increase in muscle protein content as compared to casein and faba bean-enriched pasta. Combe et al. [66] suggested that lysine and arginine from faba bean seeds would be only partially available for protein synthesis in peripheral tissues, e.g., skeletal muscles, as they demonstrated that lysine and arginine contents in muscle were higher in rats fed lentil (Lens escilenta) or chickpea (Cicer arietinum) than those fed faba bean (Vicia faba).

In addition to the balanced essential amino acid composition, the arginine and glycine contents were higher in legume-enriched pasta than casein and SMP diets. These amino acids are known to influence protein synthesis [67-70]. Several studies have demonstrated that dietary L-arginine supplementation enhances skeletal muscle mass and muscle protein synthesis in rats or pigs $[67,68]$. This particular effect could be dependent on an increased phosphorylation rate of the Akt/mTOR signaling pathway, which is a key driver of protein synthesis $[67,68]$. Moreover, the abundance of glycine in legume-enriched pasta is also one of the potential mechanisms leading to enhanced skeletal muscle protein anabolism in old rats. Hence, glycine could increase protein synthesis by Akt/mTOR activation and prevent protein degradation by inhibiting proteolytic gene expression [69].

Like amino acids, insulin plays a major role in promoting postprandial protein anabolism, mainly by inhibiting protein degradation and activating postprandial protein synthesis [71,72]. In post-absorptive conditions, the fasting insulin and glucose levels were not statistically different between groups. Nevertheless, the postprandial insulin level could be different in old rats, according to the diet composition. We suggest that legume-enriched pasta containing gelatinized starch could stimulate insulin secretion [73] when compared to rats fed casein and SMP containing native starch. A cumulative effect of increased insulin secretion, arginine, and glycine contents with better balanced amino acid composition could contribute to the equivalent muscle protein accretion in rats fed legume-enriched pasta as compared to rats fed casein and SMP, in particular for L- and P-pasta. This could partly explain the positive effect of legume-enriched pasta, despite their lower digestibility and lower leucine content, when compared to dietary animal proteins. Legume-enriched pasta could help to overcome this process by providing a balanced amino acid composition and stimulating insulin secretion, which are the two main factors implicated in enhancing meal-related muscle protein anabolism, as aging is associated with impaired muscle anabolic response to food intake [71].

This study assessed protein synthesis at muscle level, but it could also be informative for further research to assess protein distribution in other tissues and evaluate hepatic and intestinal protein synthesis rates. We measured liver protein content and liver anabolism efficiency in old rats. Interestingly, these parameters were higher in the P-pasta group and they tended to be higher in the F-pasta group when compared to groups that were fed animal proteins. Note that, Márquez-Mota et al. [42] demonstrated in young rats that a combination of legume and cereal proteins, i.e., soy and corn protein isolates, significantly enhanced the hepatic Akt/mTOR-signaling pathway when compared to soy protein or corn protein alone and to casein, possibly through stimulation of protein synthesis. 
It would have been interesting to add another control group fed a pasta containing only wheat proteins to our research. This experimental design would have evaluated the benefit of mixing legume protein sources with wheat protein sources to compensate for the low anabolic effect of each plant protein alone. Nevertheless, the outcome of this group was expected. Impaired food efficiency, muscle mass, and nitrogen retention were observed in young rats that were fed wheat pasta enriched with gluten as compared to legume-enriched pasta group, according to previous data, as discussed above [46]. Feeding rats with diets deficient in lysine alter the nitrogen balance of animals [43-46]. Therefore, rat group fed only wheat proteins was not added in our research in order to avoid observing the consequences of lysine deficiency of cereal proteins. The comparison of our study results with those reported in the literature [43-46] led us to conclude that the enrichment of wheat pasta with legume protein sources could compensate the lower anabolic effect of wheat proteins and improve their nutritional quality, especially in old rats.

\section{Conclusions}

We demonstrated that net protein utilization in old rats fed legume-enriched pasta diets was similar to those fed a casein diet and lower than with an SMP diet. At the tissue level, legume-enriched pasta intake led to significant protein accretion in the liver. In addition, legume-enriched pasta intake induced a similar muscle protein synthesis rate to a casein diet, but a lower rate than a SMP diet. Moreover, legume enriched pasta intake led to an equivalent effect on muscle weight and muscle protein accretion in old rats when compared to casein and SMP. However, the muscle protein synthesis rate was higher in rats fed the legume-enriched pasta than in animals fed each legume source alone (based on data from previous studies). Blending wheat and legume in a staple food, like pasta, led to improve its essential amino acid profile that is more adequate for muscle synthesis rate and muscle protein accretion especially for older individuals. These new food matrices combining wheat and legume flours have an equivalent nutritional quality to that of casein regardless of the legume type used, but still lower than that of soluble milk proteins "whey proteins".

Author Contributions: Conceptualization: I.B., J.S., Y.B., V.M. and S.W.; Data curation: I.B., J.S., V.M. and S.W.; Formal analysis: I.B., J.S., V.M. and S.W.; Funding acquisition: V.M. and S.W.; Investigation: I.B., J.S., K.L., C.G.(Christelle Guillet), V.P., C.G.(Christophe Giraudet), O.L.B., M.G., P.D., C.P., A.P., P.S., Y.B., V.M. and S.W.; Methodology: I.B., J.S., Y.B., V.M. and S.W.; Project administration: J.S., Y.B., V.M. and S.W.; Resources: V.M. and S.W.; Supervision: V.M. and S.W.; Validation: I.B., J.S., V.M. and S.W.; Visualization: I.B., J.S., V.M. and S.W.; Writing - original draft: I.B., V.M. and S.W.; Writing—review \& editing: I.B., J.S., V.M. and S.W. All authors have read and agreed to the published version of the manuscript.

Funding: This research is part of the 'VEGAGE' project and was funded by the Institut Carnot-Qualiment and INRA metaprogram (Did'it).

Acknowledgments: The authors thank Philippe Lhoste, Phillipe Denis and Christophe Delhomme (INRA, Clermont Auvergne, France) for their technical assistance, and Julien Hermet (INRA, Clermont Auvergne, France) for his cooperative technical support. The authors also thank La Semoulerie de Bellevue (Groupe Panzani, Marseille, France), GEMEF Industries (Aix-en-Provence, France), Moulin des Moines (Krautwiller, France), Celnat (Saint Germain Laprade, France) and Lactalis (Torcé, France) for providing wheat semolina, faba bean, green split pea and green lentil flours, sodium caseinate, and Prolacta ${ }^{\circledR}$, respectively.

Conflicts of Interest: The authors declare no competing interests.

\section{Abbreviations}

$\begin{array}{ll}\text { AA } & \text { amino acid } \\ \text { AD } & \text { apparent digestibility } \\ \text { ASR } & \text { absolute synthesis rate } \\ \text { AT } & \text { adipose tissue } \\ \text { BCAA } & \text { branched-chain amino acid } \\ \text { BV } & \text { biological value } \\ \text { BW } & \text { bodyweight } \\ \text { EAA } & \text { essential amino acid }\end{array}$




$\begin{array}{ll}\text { EFN } & \text { endogenous fecal nitrogen } \\ \text { EUN } & \begin{array}{l}\text { endogenous urinary nitrogen } \\ \text { F-pasta }\end{array} \\ \text { faba bean-enriched pasta } \\ \text { FM } & \text { fat mass } \\ \text { FN } & \text { fecal nitrogen } \\ \text { L-pasta } & \text { lentil-enriched pasta } \\ \text { LM } & \text { lean mass } \\ \text { NB } & \text { nitrogen balance } \\ \text { NI } & \text { nitrogen intake } \\ \text { NPU } & \text { net protein utilization } \\ \text { P-pasta } & \text { split pea-enriched pasta } \\ \text { SMP } & \text { soluble milk proteins } \\ \text { TD } & \text { true digestibility } \\ \text { TIA } & \text { trypsin inhibitor activity } \\ \text { TMM } & \text { total skeletal muscle mass } \\ \text { UN } & \text { urinary nitrogen }\end{array}$

\section{References}

1. Cruz-Jentoft, A.J.; Bahat, G.; Bauer, J.; Boirie, Y.; Bruyère, O.; Cederholm, T.; Cooper, C.; Landi, F.; Rolland, Y.; Sayer, A.A.; et al. Sarcopenia: Revised European consensus on definition and diagnosis. Age Ageing 2019, 48, 16-31. [CrossRef]

2. Dardevet, D.; Sornet, C.; Balage, M.; Grizard, J. Stimulation of in vitro rat muscle protein synthesis by leucine decreases with age. J. Nutr. 2000, 130, 2630-2635. [CrossRef] [PubMed]

3. Volpi, E.; Mittendorfer, B.; Rasmussen, B.B.; Wolfe, R.R. The response of muscle protein anabolism to combined hyperaminoacidemia and glucose-induced hyperinsulinemia is impaired in the elderly. J. Clin. Endocrinol. Metab. 2000, 85, 4481-4490. [CrossRef] [PubMed]

4. Guillet, C.; Prod'homme, M.; Balage, M.; Gachon, P.; Giraudet, C.; Morin, L.; Grizard, J.; Boirie, Y. Impaired anabolic response of muscle protein synthesis is associated with $\mathrm{S} 6 \mathrm{~K} 1$ dysregulation in elderly humans. FASEB J. 2004, 18, 1586-1587. [CrossRef] [PubMed]

5. Guillet, C.; Zangarelli, A.; Gachon, P.; Morio, B.; Giraudet, C.; Rousset, P.; Boirie, Y. Whole body protein breakdown is less inhibited by insulin, but still responsive to amino acid, in nondiabetic elderly subjects. J. Clin. Endocrinol. Metab. 2004, 89, 6017-6024.

6. Dardevet, D.; Rémond, D.; Peyron, M.A.; Papet, I.; Savary-Auzeloux, I.; Mosoni, L. Muscle wasting and resistance of muscle anabolism: The "anabolic threshold concept" for adapted nutritional strategies during sarcopenia. Sci. World J. 2012, 2012, 269-531. [CrossRef]

7. Bauer, J.; Biolo, G.; Cederholm, T.; Cesari, M.; Cruz-Jentoft, A.J.; Morley, J.E.; Phillips, S.; Sieber, C.; Stehle, P.; Teta, D.; et al. Evidence-based recommendations for optimal dietary protein intake in older people: A position paper from the PROT-AGE Study Group. J. Am. Med. Dir. Assoc. 2013, 14, 542-559. [CrossRef]

8. Traylor, D.A.; Gorissen, S.H.M.; Phillips, S.M. Perspective: Protein requirements and optimal intakes in aging: Are we ready to recommend more than the recommended daily allowance? Adv. Nutr. 2018, 9, 171-182. [CrossRef]

9. Walrand, S.; Boirie, Y. Optimizing protein intake in aging. Curr. Opin. Clin. Nutr. Metab. Care 2005, 8, 89-94. [CrossRef]

10. van Vliet, S.; Burd, N.A.; van Loon, L.J.C. The skeletal muscle anabolic response to plant- versus animal-based protein consumption. J. Nutr. 2015, 145, 1981-1991. [CrossRef]

11. Gorissen, S.H.M.; Witard, O.C. Characterising the muscle anabolic potential of dairy, meat and plant-based protein sources in older adults. Proc. Nutr. Soc. 2018, 77, 20-31. [PubMed]

12. Berrazaga, I.; Micard, V.; Gueugneau, M.; Walrand, S. The Role of the Anabolic Properties of Plant- versus Animal-Based Protein Sources in Supporting Muscle Mass Maintenance: A Critical Review. Nutrients 2019, 11, 1825. [CrossRef] [PubMed]

13. Artaud-Wild, S.M.; Connor, S.L.; Sexton, G.; Connor, W.E. Differences in coronary mortality can be explained by differences in cholesterol and saturated fat intakes in 40 countries but not in France and Finland. A paradox. Circulation 1993, 88, 2771-2779. [CrossRef] [PubMed] 
14. Bernstein, A.M.; Sun, Q.; Hu, F.B.; Stampfer, M.J.; Manson, J.E.; Willett, W.C. Major dietary protein sources and risk of coronary heart disease in women. Circulation 2010, 122, 876-883. [CrossRef]

15. Pan, A.; Sun, Q.; Bernstein, A.M.; Schulze, M.B.; Manson, J.E.; Stampfer, M.J.; Willett, W.C.; Hu, F.B. Red Meat Consumption and Mortality: Results from Two Prospective Cohort Studies. Arch. Intern. Med. 2012, 172, 555-563.

16. Asif, M.; Rooney, L.W.; Ali, R.; Riaz, M.N. Application and opportunities of pulses in food system: A review. Crit. Rev. Food Sci. Nutr. 2013, 53, 1168-1179. [CrossRef]

17. Zhu, F.; Du, B.; Xu, B. Anti-inflammatory effects of phytochemicals from fruits, vegetables, and food legumes: A review. Crit. Rev. Food Sci. Nutr. 2018, 58, 1260-1270. [CrossRef]

18. Martínez, J.A.; Larralde, J. Influence of diets containing different levels of Vicia faba L. as source of protein on body Protein composition and nitrogen balance of growing rats. Ann. Nutr. Metab. 1984, 28, 174-180.

19. Martínez, J.A.; Larralde, J. Muscle protein turnover in rats fed on diets containing different levels of Vicia faba L. and casein as source of protein. Rev. Esp. Fisiol. 1984, 40, 109-115.

20. Martínez, J.A.; Larralde, J. Developmental changes on protein turnover in growing rats fed on diets containing field beans (Vicia faba L.) as source of protein. Arch. Latinoam. Nutr. 1984, 34, 466-476.

21. Martínez, J.A.; Goena, M.; Santidrián, S.; Larralde, J. Response of muscle, liver and whole-body protein turnover to two different sources of protein in growing rats. Ann. Nutr. Metab. 1987, 31, 146-153. [PubMed]

22. Martinez, J.; Marcos, R.; Macarulla, M.; Larralde, J. Growth, hormonal status and protein-turnover in rats fed on a diet containing peas (Pisum-sativum L.) as the source of protein. Plant. Foods Hum. Nutr. 1995, 47, 211-220. [CrossRef] [PubMed]

23. Pirman, T.; Stekar, J.M.A.; Combe, E.; Orešnik, A. Nutritional value of beans and lentils in rats. Krmiva 2001, 43, 133-143.

24. Pirman, T.; Combe, E.; Ribeyre, M.C.; Prugnaud, J.; Stekar, J.; Patureau Mirand, P. Differential effects of cooked beans and cooked lentils on protein metabolism in intestine and muscle in growing rats. Ann. Nutr. Metab. 2006, 50, 197-205. [CrossRef] [PubMed]

25. Alonso, R.; Grant, G.; Frühbeck, G.; Marzo, F. Muscle and liver protein metabolism in rats fed raw or heat-treated pea seeds. J. Nutr. Biochem. 2002, 13, 611-618. [CrossRef]

26. Combe, E.; Pirman, T.; Stekar, J.; Houlier, M.-L.; Mirand, P.P. Differential effect of lentil feeding on proteosynthesis rates in the large intestine, liver and muscle of rats. J. Nutr. Biochem. 2004, 15, 12-17. [CrossRef]

27. Deutz, N.E.; Bruins, M.J.; Soeters, P.B. Infusion of soy and casein protein meals affects interorgan amino acid metabolism and urea kinetics differently in pigs. J. Nutr. 1998, 128, 2435-2445. [CrossRef]

28. Bos, C.; Metges, C.C.; Gaudichon, C.; Petzke, K.J.; Pueyo, M.E.; Morens, C.; Everwand, J.; Benamouzig, R.; Tomé, D. Postprandial kinetics of dietary amino acids are the main determinant of their metabolism after soy or milk protein ingestion in humans. J. Nutr. 2003, 133, 1308-1315. [CrossRef]

29. Luiking, Y.C.; Deutz, N.E.P.; Jäkel, M.; Soeters, P.B. Casein and soy protein meals differentially affect whole-body and splanchnic protein metabolism in healthy humans. J. Nutr. 2005, 135, 1080-1087. [CrossRef]

30. Hartman, J.W.; Tang, J.E.; Wilkinson, S.B.; Tarnopolsky, M.A.; Lawrence, R.L.; Fullerton, A.V.; Phillips, S.M. Consumption of fat-free fluid milk after resistance exercise promotes greater lean mass accretion than does consumption of soy or carbohydrate in young, novice, male weightlifters. Am. J. Clin. Nutr. 2007, 86, 373-381.

31. Wilkinson, S.B.; Tarnopolsky, M.A.; Macdonald, M.J.; Macdonald, J.R.; Armstrong, D.; Phillips, S.M. Consumption of fluid skim milk promotes greater muscle protein accretion after resistance exercise than does consumption of an isonitrogenous and isoenergetic soy-protein beverage. Am. J. Clin. Nutr. 2007, 85, 1031-1040. [CrossRef] [PubMed]

32. Tang, J.E.; Moore, D.R.; Kujbida, G.W.; Tarnopolsky, M.A.; Phillips, S.M. Ingestion of whey hydrolysate, casein, or soy protein isolate: Effects on mixed muscle protein synthesis at rest and following resistance exercise in young men. J. Appl. Physiol. 2009, 107, 987-992. [CrossRef] [PubMed]

33. Norton, L.E.; Wilson, G.J.; Layman, D.K.; Moulton, C.J.; Garlick, P.J. Leucine content of dietary proteins is a determinant of postprandial skeletal muscle protein synthesis in adult rats. Nutr. Metab. 2012, 9, 67. [CrossRef] [PubMed]

34. Kanda, A.; Nakayama, K.; Sanbongi, C.; Nagata, M.; Ikegami, S.; Itoh, H. Effects of whey, caseinate, or milk protein ingestion on muscle protein synthesis after exercise. Nutrients 2016, 8, 339. [CrossRef] 
35. Wróblewska, B.; Juśkiewicz, J.; Kroplewski, B.; Jurgoński, A.; Wasilewska, E.; Złotkowska, D.; Markiewicz, L. The effects of whey and soy proteins on growth performance, gastrointestinal digestion, and selected physiological responses in rats. Food Funct. 2018, 9, 1500-1509. [CrossRef]

36. Berrazaga, I.; Mession, J.L.; Laleg, K.; Salles, J.; Guillet, C.; Patrac, V.; Giraudet, C.; Le Bacquer, O.; Boirie, Y.; Micard, V.; et al. Formulation, process conditions, and biological evaluation of dairy mixed gels containing fava bean and milk proteins: Effect on protein retention in growing young rats. J. Dairy Sci. 2019, 102, 1066-1082. [CrossRef]

37. Yang, Y.; Churchward-Venne, T.A.; Burd, N.A.; Breen, L.; Tarnopolsky, M.A.; Phillips, S.M. Myofibrillar protein synthesis following ingestion of soy protein isolate at rest and after resistance exercise in elderly men. Nutr. Metab. 2012, 9, 57. [CrossRef]

38. Gorissen, S.H.; Horstman, A.M.; Franssen, R.; Crombag, J.J.; Langer, H.; Bierau, J.; Respondek, F.; van Loon, L.J. Ingestion of wheat protein increases in vivo muscle protein synthesis rates in healthy older men in a randomized trial. J. Nutr. 2016, 146, 1651-1659. [CrossRef]

39. FAO. Dietary Protein Evaluation in Human Nutrition: Report of an FAO Expert Consultation 2011; FAO Food and Nutrition Paper, 92; FAO: Rome, Italy, 2013.

40. Boye, J.; Zare, F.; Pletch, A. Pulse proteins: Processing, characterization, functional properties and applications in food and feed. Food Res. Int. 2010, 43, 414-431. [CrossRef]

41. Duranti, M. Grain legume proteins and nutraceutical properties. Fitoterapia 2006, 77, 67-82. [CrossRef]

42. Márquez-Mota, C.C.; Rodriguez-Gaytan, C.; Adjibade, P.; Mazroui, R.; Gálvez, A.; Granados, O.; Tovar, A.R.; Torres, N. The mTORC1-signaling pathway and hepatic polyribosome profile are enhanced after the recovery of a protein restricted diet by a combination of soy or black bean with corn protein. Nutrients 2016, 8, 573. [CrossRef] [PubMed]

43. Torres, A.; Frias, J.; Granito, M.; Vidal-Valverde, C. Fermented pigeon pea (Cajanus cajan) ingredients in pasta products. J. Agric. Food Chem. 2006, 54, 6685-6691. [CrossRef] [PubMed]

44. Torres, A.; Frias, J.; Granito, M.; Guerra, M.; Vidal-Valverde, C. Chemical, biological and sensory evaluation of pasta products supplemented with $\alpha$-galactoside-free lupin flours. J. Sci. Food Agric. 2007, 87, 74-81. [CrossRef]

45. Torres, A.; Frias, J.; Granito, M.; Vidal-Valverde, C. Germinated Cajanus cajan seeds as ingredients in pasta products: Chemical, biological and sensory evaluation. Food Chem. 2007, 101, 202-211. [CrossRef]

46. Laleg, K.; Salles, J.; Berry, A.; Giraudet, C.; Patrac, V.; Guillet, C.; Denis, P.; Tessier, F.J.; Guilbaud, A.; Howsam, M.; et al. Nutritional evaluation of mixed wheat-faba bean pasta in growing rats: Impact of protein source and drying temperature on protein digestibility and retention. Br. J. Nutr. 2019, 121, 496-507. [CrossRef]

47. Giménez, M.A.; Drago, S.R.; Bassett, M.N.; Lobo, M.O.; Sammán, N.C. Nutritional improvement of corn pasta-like product with broad bean (Vicia faba) and quinoa (Chenopodium quinoa). Food Chem. 2016, 199, 150-156. [CrossRef]

48. Laleg, K.; Cassan, D.; Abecassis, J.; Micard, V. Procédé de Fabrication de Pâte Destinée à L'alimentation Humaine et/ou Animale Comprenant au Moins 35\% de Légumineuse. Institut National de la Recherche Agronomique (INRA) —Centre International D'etudes Superieures en Sciences Agronomiques (SupAgro). France. Google Patents WO2016097328 A1, 23 June 2016.

49. Babault, N.; Deley, G.; Le Ruyet, P.; Morgan, F.; Allaert, F.A. Effects of soluble milk protein or casein supplementation on muscle fatigue following resistance training program: A randomized, double-blind, and placebo-controlled study. J. Int. Soc. Sports Nutr. 2014, 11, 36. [CrossRef]

50. Dumas, A. Stickstoffbestimmung Nach Dumas. Die Praxis des Org. Chemikers. (N-Determination According to Dumas), 41th ed.; Schrag: Nuremberg, Germany, 1962.

51. Proll, J.; Petzke, K.J.; Ezeagu, I.E.; Metges, C.C. Low nutritional quality of unconventional tropical crop seeds in rats. J. Nutr. 1998, 128, 2014-2022. [CrossRef]

52. Mantha, O.L.; Polakof, S.; Huneau, J.-F.; Mariotti, F.; Poupin, N.; Zalko, D.; Fouillet, H. Early changes in tissue amino acid metabolism and nutrient routing in rats fed a high-fat diet: Evidence from natural isotope abundances of nitrogen and carbon in tissue proteins. Br. J. Nutr. 2018, 119, 981-991. [CrossRef]

53. Salles, J.; Chanet, A.; Berry, A.; Giraudet, C.; Patrac, V.; Domingues-Faria, C.; Rocher, C.; Guillet, C.; Denis, P.; Pouyet, C.; et al. Fast digestive, leucine-rich, soluble milk proteins improve muscle protein anabolism, and mitochondrial function in undernourished old rats. Mol. Nutr. Food Res. 2017, 61, 1700287. [CrossRef] 
54. Moore, D.R.; Soeters, P.B. The Biological Value of Protein. Nestle Nutr. Inst. Workshop Ser. 2015, 82, 39-51. [PubMed]

55. Sarwar, G.; Peace, R.W.; Botting, H.G.; Brulé, D. Digestibility of protein and amino acids in selected foods as determined by a rat balance method. Plant. Foods Hum. Nutr. 1989, 39, 23-32. [CrossRef] [PubMed]

56. Liener, I.E.; Goodale, R.L.; Deshmukh, A.; Satterberg, T.L.; Ward, G.; DiPietro, C.M.; Bankey, P.E.; Borner, J.W. Effect of a trypsin inhibitor from soybeans (Bowman-Birk) on the secretory activity of the human pancreas. Gastroenterology 1988, 94, 419-427. [CrossRef]

57. Berrazaga, I.; Bourlieu-Lacanal, C.; Laleg, K.; Jardin, J.; Briard-Bion, V.; Dupont, D.; Walrand, S.; Micard, V. Effect of protein aggregation in wheat-legume mixed pasta diets on their in vitro digestion kinetics in comparison to "rapid" and "slow" animal proteins. PLoS ONE 2020, 15, e0232425. [CrossRef]

58. Kim, Y.A.; Barbeau, W.E. Changes in the nutritive value of soy protein concentrate during autoclaving. Plant. Foods Hum. Nutr. 1991, 41, 179-192. [CrossRef]

59. Sun-Waterhouse, D.; Zhao, M.; Waterhouse, G. Protein Modification During Ingredient Preparation and Food Processing: Approaches to Improve Food Processability and Nutrition. Food Bioprocess. Technol. 2014, 7, 1853-1893. [CrossRef]

60. Löhrke, B.; Saggau, E.; Schadereit, R.; Beyer, M.; Bellmann, O.; Kuhla, S.; Hagemeister, H. Activation of skeletal muscle protein breakdown following consumption of soyabean protein in pigs. Br. J. Nutr. 2001, 85, 447-457. [CrossRef]

61. NRC National Research Council. Nutrient Requirements of Laboratory Animals, 4th ed.; National Academic Press: Washington, DC, USA, 1995.

62. Boirie, Y.; Dangin, M.; Gachon, P.; Vasson, M.P.; Maubois, J.L.; Beaufrère, B. Slow and fast dietary proteins differently modulate postprandial protein accretion. Proc. Natl. Acad. Sci. USA 1997, 94, 14930-14935. [CrossRef]

63. Rieu, I.; Balage, M.; Sornet, C.; Debras, E.; Ripes, S.; Rochon-Bonhomme, C.; Pouyet, C.; Grizard, J.; Dardevet, D. Increased availability of leucine with leucine-rich whey proteins improves postprandial muscle protein synthesis in aging rats. Nutrition 2007, 23, 323-331. [CrossRef]

64. Gryson, C.; Walrand, S.; Giraudet, C.; Rousset, P.; Migné, C.; Bonhomme, C.; Le Ruyet, P.; Boirie, Y. "Fast proteins" with a unique essential amino acid content as an optimal nutrition in the elderly: Growing evidence. Clin. Nutr. 2014, 33, 642-648. [CrossRef]

65. Walrand, S.; Gryson, C.; Salles, J.; Giraudet, C.; Migné, C.; Bonhomme, C.; Le Ruyet, P.; Boirie, Y. Fast-digestive protein supplement for ten days overcomes muscle anabolic resistance in healthy elderly men. Clin. Nutr. 2016, 35, 660-668. [PubMed]

66. Combe, E.; Achi, T.; Pion, R. Compared Metabolic and Digestive Utilizations of Faba Bean, Lentil and Chick Pea. Reprod. Nutr. Dev. 1991, 31, 631-646. [CrossRef] [PubMed]

67. Yao, K.; Yin, Y.L.; Chu, W.; Liu, Z.; Deng, D.; Li, T.; Huang, R.; Zhang, J.; Tan, B.; Wang, W.; et al. Dietary arginine supplementation increases mTOR signaling activity in skeletal muscle of neonatal pigs. J. Nutr. 2008, 138, 867-872. [CrossRef] [PubMed]

68. Jobgen, W.; Meininger, C.J.; Jobgen, S.C.; Li, P.; Lee, M.J.; Smith, S.B.; Spencer, T.E.; Fried, S.K.; Wu, G. Dietary L-arginine supplementation reduces white fat gain and enhances skeletal muscle and brown fat masses in diet-induced obese rats. J. Nutr. 2009, 139, 230-237. [PubMed]

69. Sun, K.; Wu, Z.; Ji, Y.; Wu, G. Glycine Regulates Protein Turnover by Activating Protein Kinase B/Mammalian Target of Rapamycin and by Inhibiting MuRF1 and Atrogin-1 Gene Expression in C2C12 Myoblasts. J. Nutr. 2016, 146, 2461-2467.

70. Wang, R.; Jiao, H.; Zhao, J.; Wang, X.; Lin, H. L-Arginine Enhances Protein Synthesis by Phosphorylating mTOR (Thr 2446) in a Nitric Oxide-Dependent Manner in C2C12 Cells. Oxid. Med. Cell. Longev. 2018, 2018. [CrossRef]

71. Prod'homme, M.; Rieu, I.; Balage, M.; Dardevet, D.; Grizard, J. Insulin and amino acids both strongly participate to the regulation of protein metabolism. Curr. Opin. Clin. Nutr. Metab. Care 2004, 7, 71-77. [CrossRef] 
72. Prod'homme, M.; Balage, M.; Debras, E.; Farges, M.-C.; Kimball, S.; Jefferson, L.; Grizard, J. Differential effects of insulin and dietary amino acids on muscle protein synthesis in adult and old rats. J. Physiol. 2005, 563, 235-248. [CrossRef]

73. Holm, J.; Lundquist, I.; Björck, I.; Eliasson, A.C.; Asp, N.G. Degree of starch gelatinization, digestion rate of starch in vitro, and metabolic response in rats. Am. J. Clin. Nutr. 1988, 47, 1010-1016. 